\title{
Recoverable Fluorous CBS Methodology for Asymmetric Reduction of Ketones
}

\author{
Zoltán Dalicsek, ${ }^{\mathrm{a}}$ Ferenc Pollreisz, ${ }^{\mathrm{b}}$ Ágnes Gömöry, ${ }^{\mathrm{b}}$ and Tibor Soós*,a \\ Supporting Information
${ }^{a}$ Institute of Biomolecular Chemistry, Chemical Research Center of Hungarian Academy of Sciences, Budapest, Hungary P.O. Box 17, 1525.
${ }^{b}$ Institute of Structural Chemistry, Chemical Research Center of Hungarian Academy of Sciences, Budapest, Hungary P.O. Box 17, 1525.

General Information. Nuclear Magnetic Resonance spectra (NMR) were acquired on a Bruker DRX-500 (500 MHz) instrument using TMS or $\mathrm{CDCl}_{3}$ as internal standard and Varian Gemini $2000(200 \mathrm{MHz})$ instrument using $\mathrm{CDCl}_{3}$ as internal standard. IR spectra were recorded on a Nicolet Avatar 320 FT-IR spectrophotometer and are reported in wavenumbers $\left(\mathrm{cm}^{-1}\right)$. Mass spectra were recorded on a PE Sciex API 2000 triple-quadrupole mass spectrometer equipped with a Turbo Ion Spray source and VG ZAB2-SEQ tandem mass spectrometer (high resolution mass spectra). For column chromatography, Merck Silica gel 60 was employed. Enantiomer ratios were determined by a chiral HPLC analysis using a Waters 600 and Waters 996 Photodiode Array Detector with a Chiracel OD or OJ column $(0.46 \times 25$ $\mathrm{cm}$ ) or a chiral GC analysis using Agilent 6850 with Cyclosil-B column (30 m×0.25 mm $\times 0.25$ $\mu \mathrm{m})$.

Materials. Copper powder, trimethyl borate and 1.0M BH $\mathrm{BH}_{3} \mathrm{THF}$ in THF (stabilized with $0.005 \mathrm{M} \mathrm{NaBH}_{4}$ ) were purchased from Aldrich. Perfluorooctyl iodide and nonstabilizated 1.0M $\mathrm{BH}_{3} \bullet \mathrm{THF}$ in THF were purchased from Fluka. Fluorous reverse phase silica gel (FluoroFlash $^{\mathrm{TM}}$ SPE cartridge 2 grams, $8 \mathrm{cc}$ tube) was purchased from Fluorous Technologies Inc. THF was distilled from sodium/benzophenone prior to use. DMSO and $\mathrm{CH}_{3} \mathrm{OH}$ were dried and distilled from $\mathrm{CaH}_{2}$ before use.

\section{2-[Bis-(4-bromo-phenyl)-hydroxy-methyl]-pyrrolidine-1-carboxylic acid ethyl ester (4). ${ }^{2}$}

A thoroughly dried two-necked round-bottom flask was equipped with reflux condenser, additional funnel and argon inlet. Then magnesium powder (1.06 g, $43.6 \mathrm{mmol}$, activated by 
iodine) and $100 \mathrm{~mL}$ of dry THF were placed into this apparatus. The solution of 1,4dibromobenzene $(10.0 \mathrm{~g}, 42.4 \mathrm{mmol})$ in dry THF $(20 \mathrm{~mL})$ was slowly added at such a rate that maintain reflux (Since the reaction is not so vigorous in this dilution, the reaction mixture was gently warmed to close to the boiling point of THF by external heating) When the addition was complete the mixture was refluxed for an additional $2 \mathrm{~h}$. After it was cooled down to $0{ }^{\circ} \mathrm{C}$, a solution of the L-proline derivative $(3)^{1}(2.13 \mathrm{~g}, 10.6 \mathrm{mmol})$ in dry THF (20 $\mathrm{mL}$ ) was introduced at $0{ }^{\circ} \mathrm{C}$ and the reaction mixture was stirred overnight. The reaction was quenched with saturated aqueous solution of $\mathrm{NH}_{4} \mathrm{Cl}$ and extracted with $\mathrm{CHCl}_{3}(3 \times 120 \mathrm{~mL})$. Combined organic phases were dried over $\mathrm{Na}_{2} \mathrm{SO}_{4}$ and concentrated in vacuo. The crude product was purified by column chromatography on silica gel with $\mathrm{CHCl}_{3}$ to give $\mathbf{4}$ as a white solid (2.71 g, 53\%). TLC (Merck Aluminium oxide $60 \mathrm{~F}_{254}$, hexanes : EtOAc, 5:2, $\mathrm{R}_{\mathrm{f}}=0.79$ ).

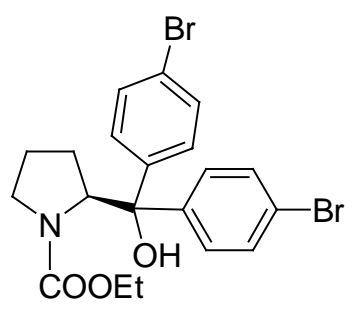

${ }^{1} \mathrm{H}-\mathrm{NMR}\left(500 \mathrm{MHz}, \mathrm{CDCl}_{3}, \delta_{\mathrm{TMS}}=0 \mathrm{ppm}\right) 7.44-7.40(\mathrm{~m}, 4 \mathrm{H}), 7.26-$ $7.21(\mathrm{~m}, 4 \mathrm{H}), 4.82(\mathrm{dd}, J=9.0,4.0 \mathrm{~Hz}, 1 \mathrm{H}), 4.16-4.11(\mathrm{~m}, 2 \mathrm{H}), 3.45-$ $3.42(\mathrm{~m}, 1 \mathrm{H}), 2.96(\mathrm{~m}, 1 \mathrm{H}), 2.11-2.03(\mathrm{~m}, 1 \mathrm{H}), 1.86-1.82(\mathrm{~m}, 1 \mathrm{H})$, $1.57-1.50(\mathrm{~m}, 1 \mathrm{H}), 1.23(\mathrm{t}, J=7.0 \mathrm{~Hz}, 3 \mathrm{H}), 0.92(\mathrm{~m}, 1 \mathrm{H}) ;{ }^{13} \mathrm{C}-\mathrm{NMR}$ $\left(125 \mathrm{MHz}, \mathrm{CDCl}_{3}, \delta_{\mathrm{CDCl}_{3}}=77.01 \mathrm{ppm}\right) 158.5(\mathrm{C}=\mathrm{O}), 144.9(\mathrm{C})$, $142.4(\mathrm{C}), 131.0(\mathrm{CH}), 130.5(\mathrm{CH}), 129.8(\mathrm{CH}), 129.3(\mathrm{CH}), 121.6(\mathrm{C}), 121.5(\mathrm{C}), 81.0(\mathrm{C})$, $65.9(\mathrm{CH}), 62.1\left(\mathrm{CH}_{2}\right), 47.7\left(\mathrm{CH}_{2}\right), 29.6\left(\mathrm{CH}_{2}\right), 23.0\left(\mathrm{CH}_{2}\right), 14.6\left(\mathrm{CH}_{3}\right)$; IR $(\mathrm{KBr}) \vee 1665$, 1485, 1422, 1381, 1336, 1010, 820, $731 \mathrm{~cm}^{-1}$; HRMS $\left(\mathrm{FAB}^{+}\right)$Exact mass calculated for $\mathrm{C}_{20} \mathrm{H}_{21}{ }^{79} \mathrm{Br}^{81} \mathrm{BrNO}_{3}(\mathrm{M}+\mathrm{H})^{+}$483.9948, found: 483.9954 .

\section{1,1-Bis-(4-bromo-phenyl)-tetrahydro-pyrrolo[1,2-c]oxazol-3-one (5). ${ }^{2}$}

A solution of $4(2.90 \mathrm{~g}, 6.0 \mathrm{mmol})$ in $100 \mathrm{~mL}$ of $1 \mathrm{M} \mathrm{NaOH}$ in $\mathrm{MeOH}$ stirred at room temperature overnight. Then the solution was concentrated in vacuo at ambient temperature The residue was mixed with $100 \mathrm{~mL}$ of water and extracted with $\mathrm{CH}_{2} \mathrm{Cl}_{2}(3 \times 100 \mathrm{~mL})$. The combined organic phases were dried over $\mathrm{Na}_{2} \mathrm{SO}_{4}$ and concentrated in vacuo to furnish 5 $(2.46 \mathrm{~g}, 94 \%)$ as a white solid. TLC: (Merck Aluminium oxide $60 \mathrm{~F}_{254}$, hexanes : EtOAc 5:2, $\left.\mathrm{R}_{\mathrm{f}}=0.63\right)$.

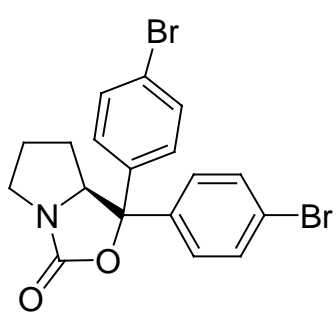

${ }^{1} \mathrm{H}-\mathrm{NMR}\left(500 \mathrm{MHz}, \mathrm{CDCl}_{3}, \delta_{\mathrm{TMS}}=0 \mathrm{ppm}\right) 7.50-7.46(\mathrm{~m}, 4 \mathrm{H}), 7.35$ $(\mathrm{d}, J=8.5 \mathrm{~Hz}, 2 \mathrm{H}), 7.22(\mathrm{~d}, J=8.5 \mathrm{~Hz}, 2 \mathrm{H}) 4.46(\mathrm{dd}, J=10.5,5.5 \mathrm{~Hz}$, 1H), 3.74-3.69 (m, 1H), 3.27-3.22 (m, 1H), 2.03-1.86 (m, 2H), 1.79$1.70(\mathrm{~m}, 1 \mathrm{H}), 1.17-1.02(\mathrm{~m}, 1 \mathrm{H}) ;{ }^{13} \mathrm{C}-\mathrm{NMR}\left(125 \mathrm{MHz}, \mathrm{CDCl}_{3}, \delta_{\mathrm{CDCl}_{3}}\right.$ 
$=77.01 \mathrm{ppm}) 159.8(\mathrm{C}=\mathrm{O}), 141.8(\mathrm{C}), 138.8(\mathrm{C}), 131.8(\mathrm{CH}), 131.6(\mathrm{CH}), 127.9(\mathrm{CH}), 127.2$ $(\mathrm{CH}), 84.9(\mathrm{C}), 68.8(\mathrm{CH}), 46.0\left(\mathrm{CH}_{2}\right), 28.9\left(\mathrm{CH}_{2}\right), 24.7\left(\mathrm{CH}_{2}\right)$; IR $(\mathrm{KBr})$ v 1756, 1488, 1399, 1374, 1226, 1054, 1001, $814 \mathrm{~cm}^{-1}$; HRMS $\left(\mathrm{FAB}^{+}\right)$Exact mass calculated for $\mathrm{C}_{18} \mathrm{H}_{15}{ }^{79} \mathrm{Br}^{81} \mathrm{BrNO}_{2}(\mathrm{M}+\mathrm{H})^{+}$437.9527, found: 437.9508.

\section{1,1-Bis-(4-heptadecafluorooctyl-phenyl)-tetrahydro-pyrrolo[1,2-c]oxazol-3-one (6). ${ }^{2}$}

To a mixture of freshly activated copper powder ${ }^{3}(1.45 \mathrm{~g}, 22.9 \mathrm{mmol})$, proline derivative (5) $(1.00 \mathrm{~g}, 2.3 \mathrm{mmol})$ and $50 \mathrm{~mL}$ of dry DMSO was added perfluorooctyl iodide $(3.75 \mathrm{~g}, 6.9$ mmol) over a period of ca 30 minutes at $120{ }^{\circ} \mathrm{C}$. To avoid the evaporation of the volatile perfluorooctyl iodide, intensive cooling of the reflux condenser was employed. Moreover, to

minimize the thermal decomposition of $\mathrm{R}_{\mathrm{f} 8} \mathrm{CuI}$ complex, the reaction temperature had to keep below $130{ }^{\circ} \mathrm{C}$. After stirring for $24 \mathrm{~h}$, the reaction mixture was cooled down to room temperature and diluted with $20 \mathrm{~mL}$ of diethyl ether. Then the mixture was filtered through celite pad which was washed with additional diethyl ether $(4 \times 50 \mathrm{~mL})$. The combined organic phases were washed with brine $(4 \times 50 \mathrm{~mL})$, dried over $\mathrm{Na}_{2} \mathrm{SO}_{4}$ and concentrated in vacuo. The crude product was purified by column chromatography on silica gel with hexanes : EtOAc 3:1 eluent to give $2.22 \mathrm{~g}(87 \%)$ of 6 as a white solid.

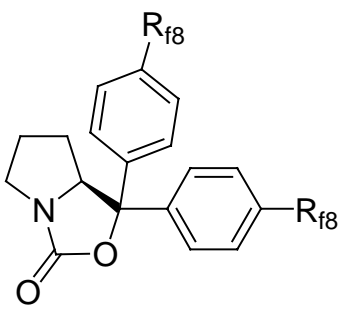

${ }^{1} \mathrm{H}-\mathrm{NMR}\left(500 \mathrm{MHz}, \mathrm{CDCl}_{3}, \delta_{\mathrm{TMS}}=0 \mathrm{ppm}\right) 7.69(\mathrm{~d}, J=8.5 \mathrm{~Hz}, 2 \mathrm{H})$, $7.64(\mathrm{~d}, J=2.5 \mathrm{~Hz}, 2 \mathrm{H}), 7.62(\mathrm{~d}, J=2.5 \mathrm{~Hz}, 2 \mathrm{H}), 7.57(\mathrm{~d}, J=8.5 \mathrm{~Hz}$, $2 \mathrm{H}), 4.57$ (dd, $J=10.5,5.5 \mathrm{~Hz}, 1 \mathrm{H}), 3.80-3.75(\mathrm{~m}, 1 \mathrm{H}), 3.31-3.26$ (m, 1H), 2.07-2.03 (m, 1H), 1.96-1.90 (m, 1H), 1.81-1.76 (m, 1H), 1.16$1.10(\mathrm{~m}, 1 \mathrm{H}) ;{ }^{13} \mathrm{C}-\mathrm{NMR}\left(125 \mathrm{MHz}, \mathrm{CDCl}_{3}, \delta_{\mathrm{CDCl}_{3}}=77.01 \mathrm{ppm}\right.$, partial $)$ $159.6(\mathrm{C}=\mathrm{O}), 146.5(\mathrm{C}), 143.6(\mathrm{C}), 129.5(\mathrm{t}, J=25 \mathrm{~Hz}, \mathrm{C}), 129.0(\mathrm{t}, J=25 \mathrm{~Hz}, \mathrm{C}), 127.5(\mathrm{t}, J$ $=5.6 \mathrm{~Hz}, \mathrm{CH}), 127.3(\mathrm{t}, \mathrm{J}=5.6 \mathrm{~Hz}, \mathrm{CH}), 126.2(\mathrm{CH}), 125.8(\mathrm{CH}), 84.7(\mathrm{C}), 69.1(\mathrm{CH}), 46.1$ $\left(\mathrm{CH}_{2}\right), 29.0\left(\mathrm{CH}_{2}\right), 24.8\left(\mathrm{CH}_{2}\right)$; IR $(\mathrm{KBr}) \vee 1760,1302,1247,1202,1151,1115 \mathrm{~cm}^{-1}$; HRMS (EI) Exact mass calculated for $\mathrm{C}_{34} \mathrm{H}_{15} \mathrm{~F}_{34} \mathrm{NO}_{2}$ (M) 1115.0418, found: 1115.0560 .

\section{Bis-(4-heptadecafluorooctyl-phenyl)-pyrrolidin-2-yl-methanol (7)}

To a mixture of $50 \mathrm{~mL}$ of $2.5 \mathrm{M} \mathrm{KOH}$ in $\mathrm{MeOH}$ and $10 \mathrm{~mL}$ of $\alpha, \alpha, \alpha$-trifluorotoluene was added fluorous prolinol derivative $(6)(0.70 \mathrm{~g}, 0.63 \mathrm{mmol})$ and stirred under reflux for $5 \mathrm{~h}$. The solution was concentrated in vacuo, mixed with $100 \mathrm{~mL}$ of water and extracted with 
$\mathrm{CH}_{2} \mathrm{Cl}_{2}(3 \times 100 \mathrm{~mL})$. The combined organic phases were washed with brine $(4 \times 50 \mathrm{~mL})$, dried over $\mathrm{Na}_{2} \mathrm{SO}_{4}$ and concentrated in vacuo to furnish 7 as a white solid $(0.67 \mathrm{~g}, 98 \%)$.

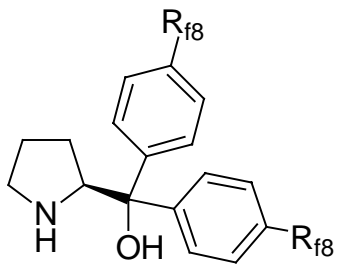

$$
\begin{aligned}
& { }^{1} \mathrm{H}-\mathrm{NMR}\left(500 \mathrm{MHz}, \mathrm{CDCl}_{3}, \delta_{\mathrm{TMS}}=0 \mathrm{ppm}\right) 7.74(\mathrm{~d}, J=8.4 \mathrm{~Hz}, 2 \mathrm{H}), \\
& 7.66(\mathrm{~d}, J=8.4 \mathrm{~Hz}, 2 \mathrm{H}), 7.53(\text { pseudot}, J=8.5 \mathrm{~Hz}, 4 \mathrm{H}), 4.83(\mathrm{br} \mathrm{s}, \\
& 1 \mathrm{H}), 4.31(\mathrm{t}, J=7.5 \mathrm{~Hz}, 1 \mathrm{H}), 3.09-3.05(\mathrm{~m}, 1 \mathrm{H}), 3.02-2.97(\mathrm{~m}, 1 \mathrm{H}), \\
& 1.81-1.56(\mathrm{~m}, 5 \mathrm{H}),{ }^{13} \mathrm{C}-\mathrm{NMR}\left(125 \mathrm{MHz}, \mathrm{CDCl}_{3}, \delta_{\mathrm{CDCl}_{3}}=77.01 \mathrm{ppm},\right.
\end{aligned}
$$
partial) $151.6(\mathrm{C}), 148.7(\mathrm{C}), 127.6(\mathrm{t}, J=23.8 \mathrm{~Hz}, \mathrm{C}) 127.4$ (t, $J=23.8 \mathrm{~Hz}, \mathrm{C}), 127.1$ (t, $J=$ $5.6 \mathrm{~Hz} \mathrm{CH}), 126.8(\mathrm{t}, J=5.6 \mathrm{~Hz}, \mathrm{CH}), 126.2(\mathrm{CH}), 125.8(\mathrm{CH}), 77.0(\mathrm{C}), 64.3(\mathrm{CH}), 46.8$ $\left(\mathrm{CH}_{2}\right), 26.4\left(\mathrm{CH}_{2}\right), 25.5\left(\mathrm{CH}_{2}\right)$; IR $(\mathrm{KBr}) \vee 1302,1248,1202,1149,1116 \mathrm{~cm}^{-1}$; HRMS $\left(\mathrm{FAB}^{+}\right)$Exact mass calculated for $\mathrm{C}_{33} \mathrm{H}_{17} \mathrm{~F}_{34} \mathrm{NO}(\mathrm{M}+\mathrm{H})^{+}$1090.0846, found: 1090.0762.

\section{3,3-Bis-(4-heptadecafluorooctyl-phenyl)-1-methyl-tetrahydro-pyrrolo[1,2-c][1,3,2] oxazaborole (8a)}

To a solution of diphenyl prolinol $7(100 \mathrm{mg}, 0.09 \mathrm{mmol})$ in dry toluene was added methylboronic acid $(6.0 \mathrm{mg}, 0.1 \mathrm{mmol})$ and refluxed for $3 \mathrm{~h}$ using a Dean-Stark trap. The reaction was drive to completion by azeotropic removal of water. The crude product was obtained by concentration of the reaction mixture in vacuo. Although the HRMS spectra indicated the formation of desired compound 8a, formation of byproducts can be seen in NMR spectra.

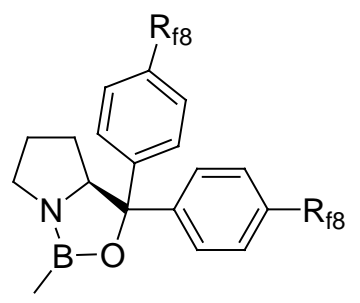

HRMS (EI) Exact mass calculated for $\mathrm{C}_{34} \mathrm{H}_{18} \mathrm{BF}_{34} \mathrm{NO}(\mathrm{M}) 1113.0938$, found: 1113.0921 .

\section{i. Procedure for asymmetric reduction of acetophenone (9) with 8a.}

The crude catalyst $8 \mathbf{a}(50.0 \mathrm{mg}, 0.045 \mathrm{mmol})$ was dissolved in $0.5 \mathrm{~mL}$ of $1 \mathrm{M} \mathrm{BH}_{3} \cdot \mathrm{THF}(0.5$ mmol, stabilized with $0.005 \mathrm{NaBH}_{4}$ ) in THF (2 equiv $\mathrm{BH}_{3}$ ) under argon atmosphere at room temperature. Then a solution of acetophenone $(9,30.0 \mathrm{mg}, 0.25 \mathrm{mmol})$ in $1 \mathrm{~mL}$ of dry THF was added slowly over a period of $30 \mathrm{~min}$. The reaction mixture was stirred for additional 30 minutes to complete. Then it was quenched with $1.0 \mathrm{~mL}$ of $\mathrm{MeOH}$, followed by the addition 
of $1 \mathrm{~mL}$ of $\mathrm{H}_{2} \mathrm{O}$ which induced the instant precipitation of fluorous compounds. This heterogeneous mixture was loaded on and filtered through fluorous silica gel (FluoroFlash ${ }^{\mathrm{TM}}$ ) followed by $\mathrm{MeOH}$-water 1:1 $(4 \times 2.5 \mathrm{~mL})$ washing to elute all nonfluorous products. Then the combined filtrates were concentrated in vacuo to remove organic solvents and the chiral secunder alcohol 10 was extracted with chloroform $(3 \times 5 \mathrm{~mL})$. The combined organic phases was dried over $\mathrm{Na}_{2} \mathrm{SO}_{4}$ and evaporated in vacuo. The enantioselectivity was determined by chiral GC (Cyclosil-B, $1.3 \mathrm{~mL} / \mathrm{min}, 120{ }^{\circ} \mathrm{C}$ isotherm) major $24.5 \mathrm{~min}$, minor $25.7 \mathrm{~min}$.

Finally, in a second-pass elution, all fluorous compounds were recovered by washing the fluorous silica gel (FluoroFlash $\left.{ }^{\mathrm{TM}}\right)$ with $\mathrm{THF}(4 \times 2.5 \mathrm{~mL})$. This mixture was mainly the fluorous prolinol 7 according to NMR experiment.

\section{ii. Procedure for asymmetric reduction of acetophenone (9) using in situ generated catalyst $8 b$.}

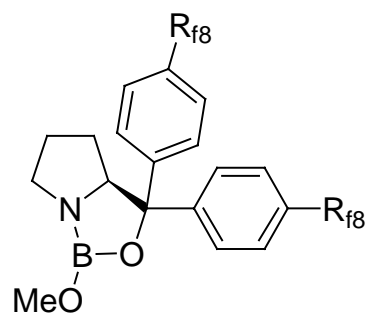

The precatalyst $7(100 \mathrm{mg}, 0,09 \mathrm{mmol})$ was dissolved in $1 \mathrm{~mL}$ of THF and trimethyl borate $(9.56 \mathrm{mg}, 0.09 \mathrm{mmol})$ was added. The mixture was stirred at room temperature for 30 minutes. Then $1 \mathrm{~mL}$ of $1 \mathrm{M} \mathrm{BH}_{3} \bullet \mathrm{THF}$ ( $1 \mathrm{mmol}$, nonstabilized) in THF ( 1 equiv $\mathrm{BH}_{3}$ ) was introduced under argon atmosphere at room temperature, followed by slow addition of acetophenone $(\mathbf{9}, 110.5 \mathrm{mg}, 0.92 \mathrm{mmol})$ in $1 \mathrm{~mL}$

of dry THF over a period of one hour. The reaction mixture was stirred for additional 30 minutes to complete. Then it was cooled to $0{ }^{\circ} \mathrm{C}$ and quenched with $0.5 \mathrm{~mL}$ of $\mathrm{MeOH}$. Addition of $2.5 \mathrm{~mL}$ of water to the reaction mixture induced the precipitation of precatalyst 7 . This heterogeneous mixture was loaded on and filtered through fluorous silica gel (FluoroFlash $\left.^{\mathrm{TM}}\right)$ followed by acetonitrile-water $1: 1(4 \times 2.5 \mathrm{~mL})$ washing to elute all nonfluorous products. Then the combined filtrates were concentrated in vacuo to remove organic solvents and the chiral secunder alcohol 10 was extracted with chloroform $(3 \times 5 \mathrm{~mL})$. The combined organic phases was dried over $\mathrm{Na}_{2} \mathrm{SO}_{4}$ and evaporated in vacuo. The enantioselectivity was determined by chiral GC $\left(1.3 \mathrm{~mL} / \mathrm{min}, 120{ }^{\circ} \mathrm{C}\right.$ isotherm $)$ major 24.5 min, minor $25.7 \mathrm{~min}$.

The fluorous precatalyst 7 was recovered in a second-pass elution of the fluorous silica gel (FluoroFlash $\left.{ }^{\mathrm{TM}}\right)$ using THF $(4 \times 2.5 \mathrm{~mL})$. The evaporation of the combined filtrates in vacuo afforded 7 (98.0 mg, 98\% efficiency) as a white solid. 


\section{iii. and iv. Procedures for the asymmetric reduction of ketones using fluorous diphenyl prolinol 7 precatalyst.}

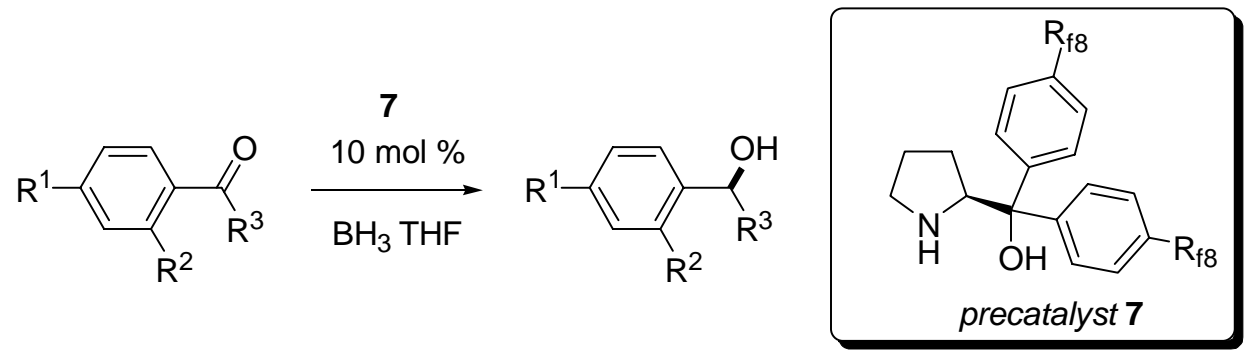

The precatalyst $7(54.50 \mathrm{mg}, 0.05 \mathrm{mmol})$ was dissolved:

iii, in $1 \mathrm{~mL}$ of $1 \mathrm{M} \mathrm{BH}_{3} \bullet \mathrm{THF}$ ( $1 \mathrm{mmol}$, nonstabilized) in THF (2 equiv $\mathrm{BH}_{3}$ ).

iv, in the mixture of $0.7 \mathrm{~mL}$ of dry THF and $0.3 \mathrm{~mL}$ of $1 \mathrm{M} \mathrm{BH}_{3} \cdot \mathrm{THF}(0.3 \mathrm{mmol}$, nonstabilized) (0.6 equiv).

under argon atmosphere at room temperature and stirred for one hour. Then a solution of ketone $(0.5 \mathrm{mmol})$ in $1 \mathrm{~mL}$ of dry THF was added slowly over a period of one hour. The reaction mixture was stirred for additional 30 minutes to complete. Then it was cooled to $0{ }^{\circ} \mathrm{C}$ and quenched with $0.5 \mathrm{~mL}$ of $\mathrm{MeOH}$. Addition of $2.5 \mathrm{~mL}$ of water to the reaction mixture induced the instant precipitation of precatalyst 7. This heterogeneous mixture was loaded on and filtered through fluorous silica gel (FluoroFlash ${ }^{\mathrm{TM}}$ ) followed by acetonitrile-water 1:1 $(4 \times 2.5 \mathrm{~mL})$ washing to elute all nonfluorous products. Then the combined filtrates were concentrated in vacuo to remove organic solvents and the chiral secunder alcohol was extracted with chloroform $(3 \times 5 \mathrm{~mL})$. The combined organic phases was dried over $\mathrm{Na}_{2} \mathrm{SO}_{4}$ and evaporated in vacuo.

The fluorous precatalyst 7 was recovered in a second-pass elution of the fluorous silica gel (FluoroFlash $\left.{ }^{\mathrm{TM}}\right)$ using THF $(4 \times 2.5 \mathrm{~mL})$. The evaporation of the combined filtrates in vacuo afforded 7 (53.95 mg, 99\% efficiency) as a white solid.

1-Phenyl-ethanol (10) ${ }^{4,6,7,9}:{ }^{1} \mathrm{H}-\mathrm{NMR}\left(200 \mathrm{MHz}, \mathrm{CDCl}_{3}\right)$ 7.40-7.25 (m, 5H, ArH), 4.88 (q, $J$ $=6.3 \mathrm{~Hz}, 1 \mathrm{H}, \mathrm{CHOH}), 2.10(\mathrm{br} \mathrm{s}, 1 \mathrm{H}, \mathrm{OH}), 1.49\left(\mathrm{~d}, J=6.3 \mathrm{~Hz}, 3 \mathrm{H}, \mathrm{CH}_{3} \mathrm{CH}\right) ;{ }^{13} \mathrm{C}-\mathrm{NMR}(50$ $\left.\mathrm{MHz}, \mathrm{CDCl}_{3}\right) 145.9(\mathrm{C}), 128.6(\mathrm{CH}), 127.6(\mathrm{CH}), 125.5(\mathrm{CH}), 70.5(\mathrm{CH}), 25.2\left(\mathrm{CH}_{3}\right)$. Enantioselectivity was determined by HPLC analysis with a Chiracel OD column, (hexane : iPrOH, 98:2), $1 \mathrm{~mL} / \mathrm{min}, \lambda=210$, retention times major: $16.0 \mathrm{~min}$, retention times minor: 20.0 $\min$. 
1-(4-Chloro-phenyl)-ethanol (12a) $)^{4,5,7,8,9}:{ }^{1} \mathrm{H}-\mathrm{NMR}\left(200 \mathrm{MHz}, \mathrm{CDCl}_{3}\right) 7.28$ (br s, 4H, ArH), $4.83(\mathrm{q}, J=6.6 \mathrm{~Hz}, 1 \mathrm{H}, \mathrm{CHOH}), 2.33$ (br s, $1 \mathrm{H}, \mathrm{OH}), 1.44\left(\mathrm{~d}, J=6.6 \mathrm{~Hz}, 3 \mathrm{H}, \mathrm{CH}_{3} \mathrm{CH}\right) ;{ }^{13} \mathrm{C}-$ NMR (APT) (50 MHz, $\left.\mathrm{CDCl}_{3}\right) 144.3(\mathrm{C}), 133.1(\mathrm{C}), 128.7$ (CH), $126.9(\mathrm{CH}), 69.8(\mathrm{CH})$, $25.3\left(\mathrm{CH}_{3}\right)$. Enantioselectivity was determined by HPLC analysis with a Chiracel OD column, (hexane : i-PrOH, 98:2), $1 \mathrm{~mL} / \mathrm{min}, \lambda=210$, retention times minor: $15.3 \mathrm{~min}$, retention times major: $17.0 \mathrm{~min}$.

1-(2,4-Dichloro-phenyl)-ethanol (12b) $)^{7,9}:{ }^{1} \mathrm{H}-\mathrm{NMR}\left(200 \mathrm{MHz}, \mathrm{CDCl}_{3}\right) 7.48$ (d, J = $8.6 \mathrm{~Hz}$, 1H, ArH), 7.31-7.21 (m, 2H, ArH), 5.18 (q, J = 6.6 Hz, 1H, CHOH), 2.48 (br s, 1H, OH), $1.42\left(\mathrm{~d}, J=6.6 \mathrm{~Hz}, 3 \mathrm{H}, \mathrm{CH}_{3} \mathrm{CH}\right) ;{ }^{13} \mathrm{C}-\mathrm{NMR}$ (APT) (50 MHz, $\left.\mathrm{CDCl}_{3}\right) 141.8(\mathrm{C}), 133.5(\mathrm{C})$, $132.2(\mathrm{C}), 129.2(\mathrm{CH}), 127.59(\mathrm{CH}), 127.52(\mathrm{CH}), 66.6(\mathrm{CH}), 23.7\left(\mathrm{CH}_{3}\right)$. Enantioselektivity was determined by HPLC analysis with a Chiracel OD column, (hexane : i-PrOH, 98:2), 1.3 $\mathrm{mL} / \mathrm{min}, \lambda=210$, retention times minor: $9.4 \mathrm{~min}$, retention times major: $10.0 \mathrm{~min}$.

1-(4-Methoxy-phenyl)-ethanol (12c) ${ }^{4,5,7,8}:{ }^{1} \mathrm{H}-\mathrm{NMR}\left(200 \mathrm{MHz}, \mathrm{CDCl}_{3}\right)$ 7.30-7.24 (m, 2H, ArH), 6.90-6.83 (m, 2H, ArH), 4.82 (q, J=6.2 Hz, 1H, CHOH), 3.79 (s, 3H, $\left.\mathrm{OCH}_{3}\right), 2.24$ (br s, $1 \mathrm{H}, \mathrm{OH}), 1.46$ (d, $\left.J=6.6 \mathrm{~Hz}, 3 \mathrm{H}, \mathrm{CH}_{3} \mathrm{CH}\right) ;{ }^{13} \mathrm{C}-\mathrm{NMR}$ (APT) $\left(50 \mathrm{MHz}, \mathrm{CDCl}_{3}\right) 159.0$ (C), $138.2(\mathrm{C}), 126.7(\mathrm{CH}), 113.9(\mathrm{CH}), 69.9(\mathrm{CH}), 55.3\left(\mathrm{CH}_{3}\right), 25.1\left(\mathrm{CH}_{3}\right)$. Enantioselectivity was determined by HPLC analysis with a Chiralcel OD column, (hexane : EtOH, 97:3), 1 $\mathrm{mL} / \mathrm{min}, \lambda=210$, retention times major $13.0 \mathrm{~min}$, retention times minor $14.5 \mathrm{~min}$.

1-Naphthalen-2-yl-ethanol (12d) ${ }^{4,5,9}:{ }^{1} \mathrm{H}-\mathrm{NMR}\left(200 \mathrm{MHz}, \mathrm{CDCl}_{3}\right)$ 7.87-7.78 (m, 4H, ArH), 7.54-7.45 (m, 3H, ArH), 5.02 (q, $J=6.4 \mathrm{~Hz}, 1 \mathrm{H}, \mathrm{CHOH}), 2.43$ (br s, 1H, OH), 1.57 (d, $J=$ $\left.6.6 \mathrm{~Hz}, 3 \mathrm{H}, \mathrm{CH}_{3} \mathrm{CH}\right){ }^{13} \mathrm{C}-\mathrm{NMR}(\mathrm{APT})\left(50 \mathrm{MHz}, \mathrm{CDCl}_{3}\right) 143.3$ (C), 133.4 (C), 133.0 (C), $128.4(\mathrm{CH}), 128.0(\mathrm{CH}), 127.8(\mathrm{CH}), 126.2(\mathrm{CH}), 125.9(\mathrm{CH}), 123.94(\mathrm{CH}), 123.90(\mathrm{CH})$, $70.5(\mathrm{CH}), 25.2\left(\mathrm{CH}_{3}\right)$. Enantioselectivity was determined by HPLC analysis with a Chiralcel OJ column, (hexane : i-PrOH, 95:5), $1 \mathrm{~mL} / \mathrm{min}, \lambda=210$, retention times minor $28.5 \mathrm{~min}$, retention times major $37.8 \mathrm{~min}$.

1-Phenyl-propan-1-ol (12e) $)^{4,6,7,9}:{ }^{1} \mathrm{H}-\mathrm{NMR}\left(200 \mathrm{MHz}, \mathrm{CDCl}_{3}\right)$ 7.37-7.24 (m, 5H, ArH), 4.58 (t, $J=6.8 \mathrm{~Hz}, 1 \mathrm{H}, \mathrm{CHOH}), 2.09$ (br s, 1H, OH), 1.90-1.67 (m, 2H, $\left.\mathrm{CH}_{2} \mathrm{CH}_{3}\right), 0.92$ (t, $J=7.3$ $\left.\mathrm{Hz}, 3 \mathrm{H}, \mathrm{CH}_{2} \mathrm{CH}_{3}\right),{ }^{13} \mathrm{C}-\mathrm{NMR}$ (APT) (50 MHz, $\mathrm{CDCl}_{3}$ ) $144.7(\mathrm{C}), 128.5(\mathrm{CH}), 127.6(\mathrm{CH})$, 126.1 $(\mathrm{CH}), 76.1(\mathrm{CH}), 32.0\left(\mathrm{CH}_{2}\right), 10.2\left(\mathrm{CH}_{3}\right)$. Enantioselectivity was determined by HPLC 
analysis with a Chiralcel OD column, (hexane : $\mathrm{i}-\mathrm{PrOH}: 95: 5), 1 \mathrm{~mL} / \mathrm{min}, \lambda=210$, retention times major $7.9 \mathrm{~min}$, retention times minor $8.7 \mathrm{~min}$.

Phenyl(o-tolyl)methanol (12f) ${ }^{10}:{ }^{1} \mathrm{H}-\mathrm{NMR}\left(200 \mathrm{MHz}, \mathrm{CDCl}_{3}\right)$ 7.55-7.51 (m, 1H, ArH), 7.357.13 (m, 8H, ArH), 5.98 (s, 1H, CH), 2.35 (br s, 1H, OH), 2.26 (s, 3H, $\left.\mathrm{CH}_{3}\right),{ }^{13} \mathrm{C}-\mathrm{NMR}$ (APT) $\left(50 \mathrm{MHz}, \mathrm{CDCl}_{3}\right) 143.0(\mathrm{C}), 141.6(\mathrm{C}), 135.5(\mathrm{C}) 130.6(\mathrm{CH}), 128.56(\mathrm{CH}), 127.64(\mathrm{CH})$, $127.62(\mathrm{CH}), 127.2(\mathrm{CH}), 126.4(\mathrm{CH}), 126.2(\mathrm{CH}), 73.5(\mathrm{CH}), 19.5\left(\mathrm{CH}_{3}\right)$. Enantioselectivity was determined by HPLC analysis with a Chiralcel OJ column, (hexane : i-PrOH : $95: 5$ ), 1 $\mathrm{mL} / \mathrm{min}, \lambda=210$, retention times major $28.4 \mathrm{~min}$, retention times minor $25.7 \mathrm{~min}$.

2-Bromocyclohex-2-enol (12g) ${ }^{11}:{ }^{13} \mathrm{C}-\mathrm{NMR}(\mathrm{APT})\left(50 \mathrm{MHz}, \mathrm{CDCl}_{3}\right) 132.7(\mathrm{CH}), 125.9(\mathrm{C})$, $70.0(\mathrm{CH}), 32.1\left(\mathrm{CH}_{2}\right), 27.9\left(\mathrm{CH}_{2}\right), 17.7\left(\mathrm{CH}_{2}\right)$. Enantioselectivity was determined by HPLC analysis with a Chiralcel OJ column, (hexane : $\mathrm{i}-\mathrm{PrOH}: 95: 5$ ), $1 \mathrm{~mL} / \mathrm{min}, \lambda=210$, retention times major $7.9 \mathrm{~min}$, retention times minor $9.3 \mathrm{~min}$.

\section{Procedure for asymmetric preparative scale catalytic reduction of acetophenone (9).}

The precatalyst $7(544.8 \mathrm{mg}, 0.5 \mathrm{mmol})$ was dissolved in the mixture of $7.0 \mathrm{~mL}$ of dry THF and $3.0 \mathrm{~mL}$ of $1 \mathrm{M} \mathrm{BH}_{3} \bullet \mathrm{THF}$ (3.0 mmol, nonstabilized) (0.6 equiv) under argon atmosphere at room temperature and stirred for one hour. Then a solution of acetophenone (9) $(600.0 \mathrm{mg}$, $5.0 \mathrm{mmol}$ ) in $10 \mathrm{~mL}$ of dry THF was added slowly over a period of one hour. The reaction mixture was stirred for additional 30 minutes to complete. Then it was cooled to $0{ }^{\circ} \mathrm{C}$ and quenched with $2.5 \mathrm{~mL}$ of $\mathrm{MeOH}$. Addition of $25 \mathrm{~mL}$ of water to the reaction mixture induced the instant precipitation of precatalyst 7. This heterogeneous mixture was loaded on and filtered through fluorous silica gel (FluoroFlash $\left.{ }^{\mathrm{TM}}\right)$ followed by acetonitrile-water $1: 1(4 \times 2.5$ $\mathrm{mL}$ ) washing to elute all nonfluorous products. Then the combined filtrates were concentrated in vacuo to remove organic solvents and the chiral secunder alcohol $\mathbf{1 0}$ was extracted with dichloromethane $(3 \times 10 \mathrm{~mL})$. The combined organic phases was dried over $\mathrm{Na}_{2} \mathrm{SO}_{4}$ and evaporated in vacuo to afford $\mathbf{1 0}$ as a colorless liquide (541.0 $\mathrm{mg}, 89 \%)$.

The fluorous precatalyst 7 was recovered in a second-pass elution of the fluorous silica gel (FluoroFlash $\left.{ }^{\mathrm{TM}}\right)$ using THF $(8 \times 2.5 \mathrm{~mL})$. The evaporation of the combined filtrates in vacuo afforded 7 (544.6 mg, >99.9\% efficiency) as a white solid. 
1. Kanth, J. V. B.; Periasamy, M. Tetrahedron 1993, 49, 5127.

2. Park, J. K.; Lee, H. G.; Bolm, C., Kim, B. M. Chem. Eur. J. 2005, 11, 945.

3. Vogel's Textbook of Practical Organic Chemistry 1989 Fifth Edition, p. 426.

4. Kobayashi ,Y.; Kodama, K.; Saigo, K. Org. Lett. 2004, 6,. 2941.

5. Hu, A.; Ngo, H. L.; Lin, W. Org. Lett. 2004, 6, 2937.

6. Jones, S.; Atherton J. C. C. Tetrahedron: Asymmetry 2000, 11, 4543.

7. Nakamura, K.; Inoue, Y.; Matsuda, T.; Misawa, I. J. Chem. Soc., Perkin Trans. 1 1999, 2397.

8. Hayashi, T.; Hirate, S.; Kitayama, K.; Tsuji, H.; Torii, A.; Uozumi, Y. J. Org. Chem. 2001, $66,1441$.

9. Standfest-Hauser, C.; Slugovc, C.; Mereiter, K.; Schmid, R.; Kirchner, K.; Xiao, L.; Weissensteiner, W. J. Chem. Soc., Dalton Trans. 2001, 2989.

10. Corey, E. J.; Helal, C. J. Tetrahedron Lett. 1996, 37, 5675.

11. Corey, E. J.; Bakshi, R. K.; Shibata, S.; Chen, C.-P.; Singh, V. K. J. Am. Chem. Soc. 1987, $109,7925$. 


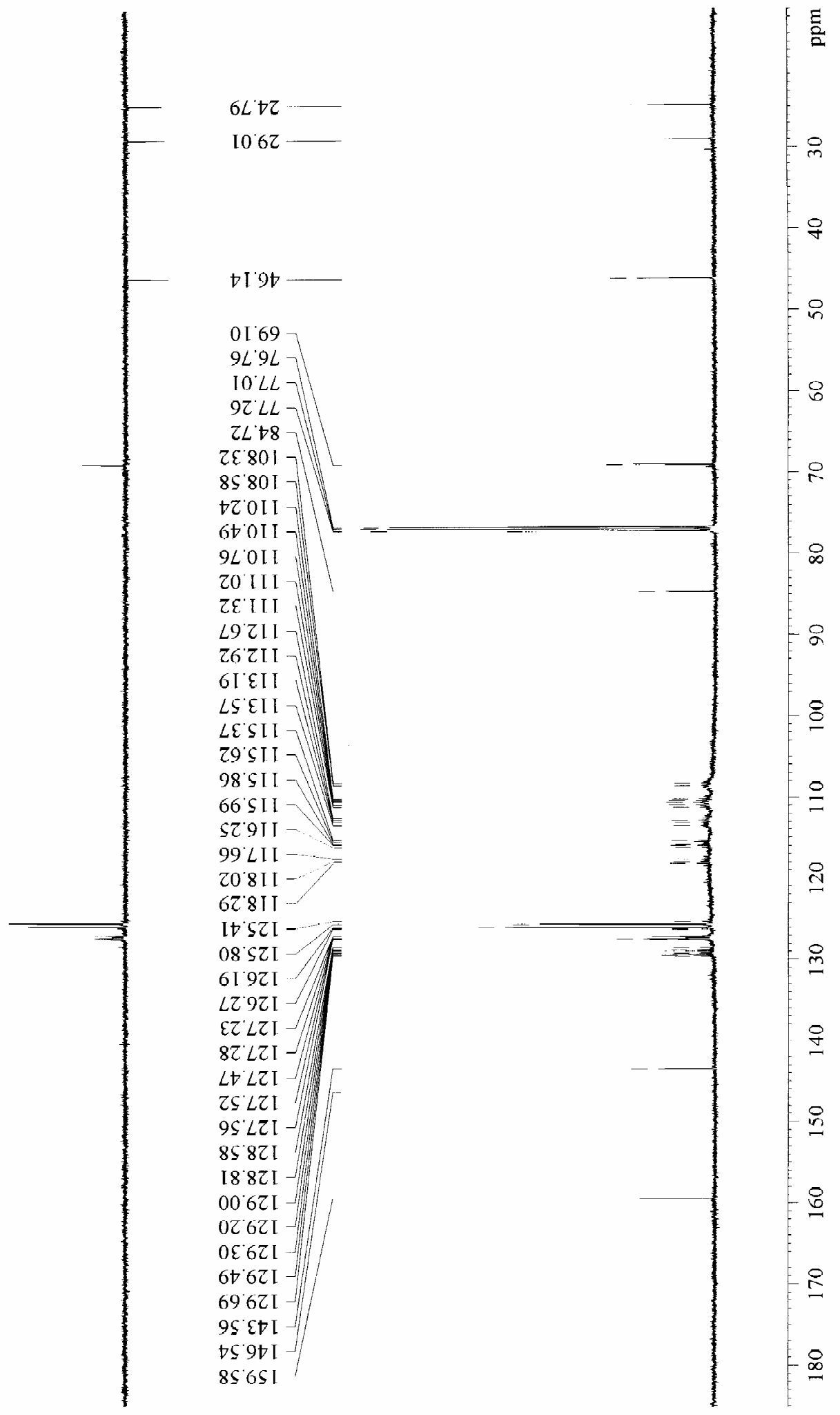

Figure 1. ${ }^{13} \mathrm{C}-\mathrm{NMR}$ spectra of 6 . 


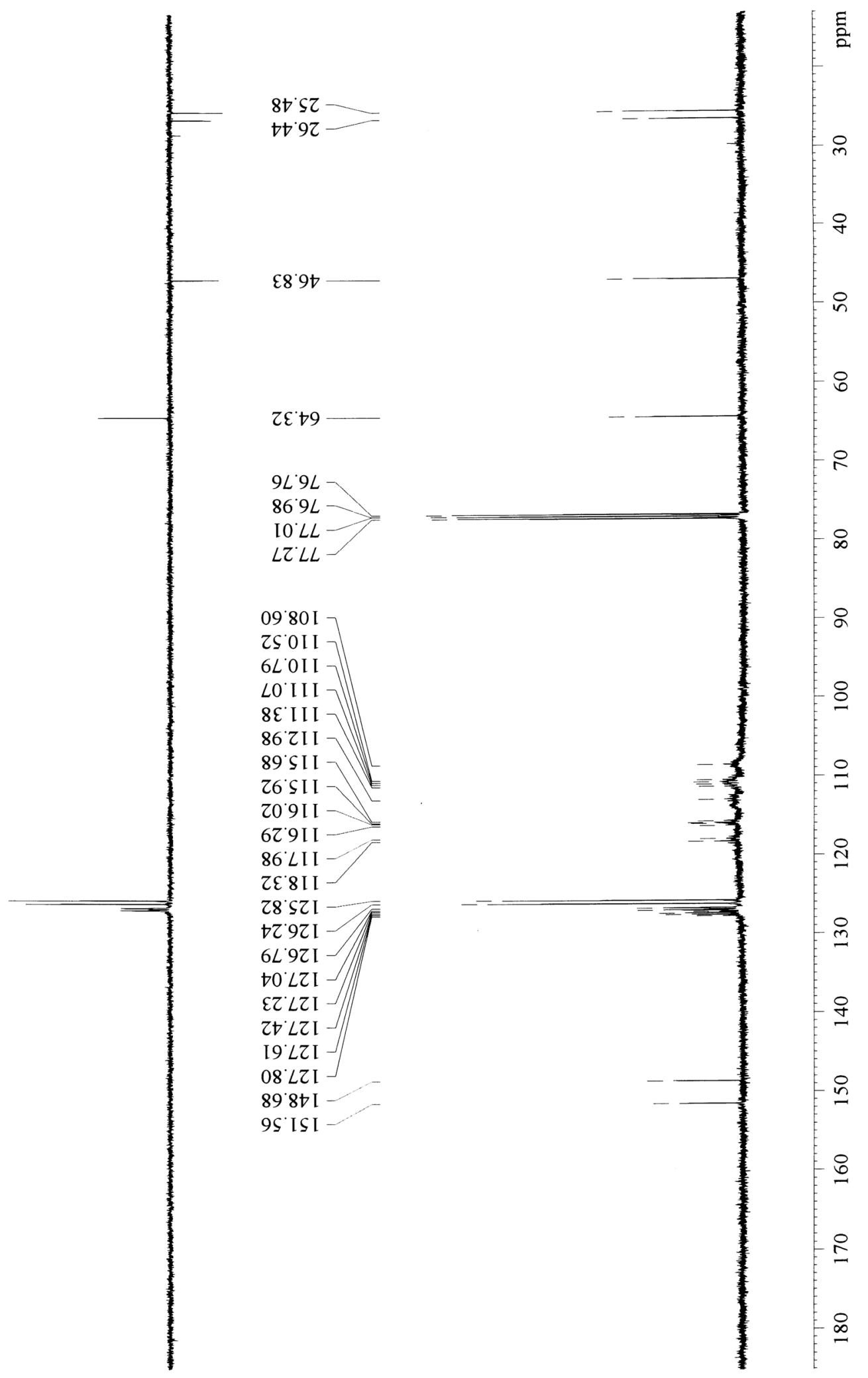

Figure 2. ${ }^{13} \mathrm{C}$-NMR spectra of 7 . 


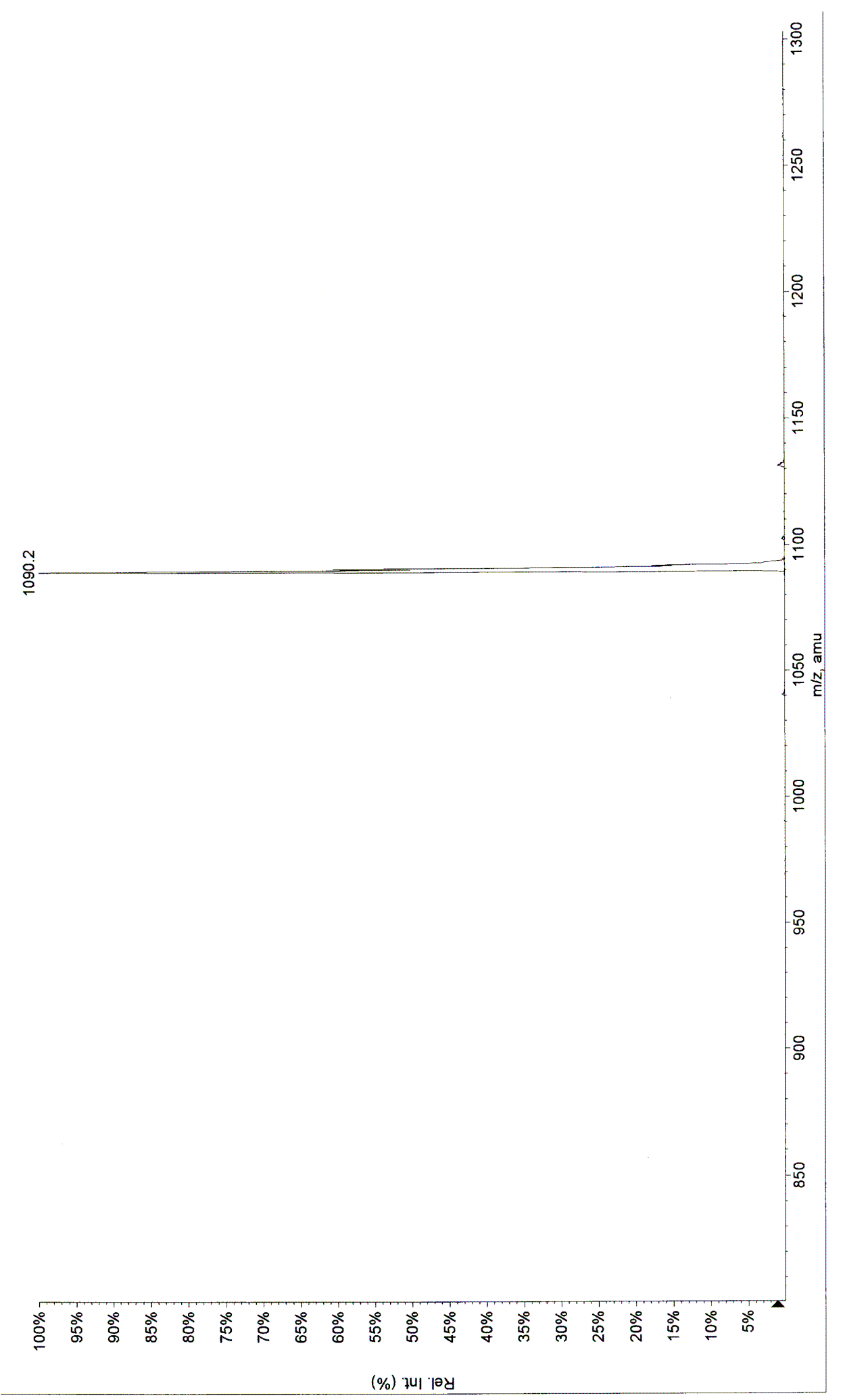

Figure 3. Mass spectra of precatalyst 7 before catalytic application. 


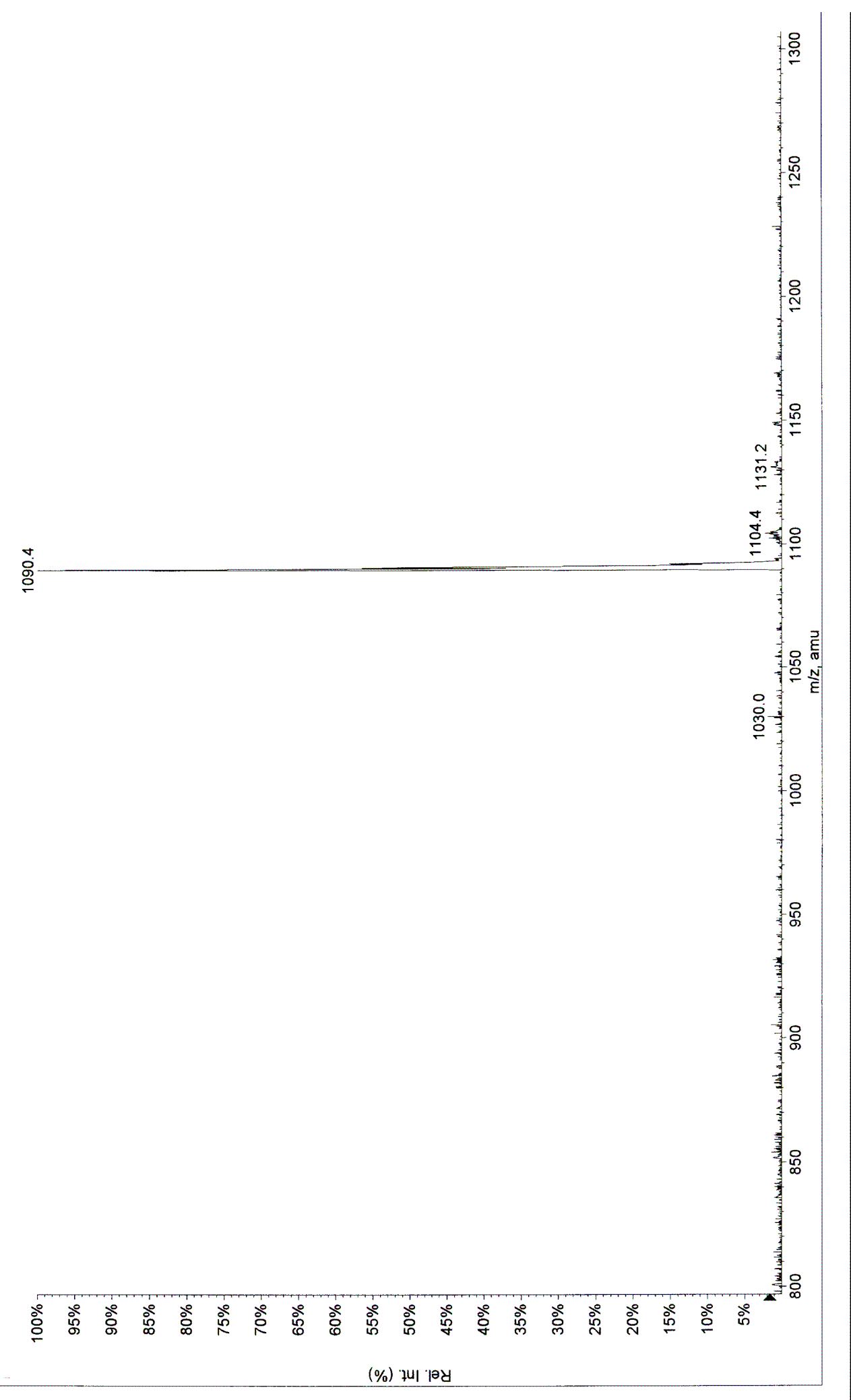

Figure 4. Mass spectra of precatalyst 7 after recovery. 